\title{
Effect of Elevated Temperature on Tribological Properties of PVD Layers
}

\author{
Mária HAGAROVÁ ${ }^{1}$, Dagmar JAKUBÉCZYOVÁ ${ }^{2}$, Miroslav DŽUPON ${ }^{2}$ \\ ${ }^{1}$ Faculty of Metallurgy, Technical University Košice, Letná 9, 04200 Košice, Slovak Republic \\ ${ }^{2}$ Institute of Materials Research of the Slovak Academy of Sciences, Watsonova 47, 04001 Košice, Slovak Republic
}

cross $^{\text {ref }}$ http://dx.doi.org/10.5755/j01.ms.22.1.7445

Received 26 June 2014; accepted 20 September 2014

\begin{abstract}
The present study investigated tribological properties of multilayer TiAlN and nanocomposite (nc-Ti1-xAlxN)/a-Si3N4) coatings. Tested coatings were deposited by two PVD methods on the high speed steel Böhler S 600 Isorapid substrate. The coatings demonstrated good adhesion to the substrate and high hardness (2090 - 2510 HV0.5). Tribological properties of the coated specimens were evaluated by the Ball-on-Disc test and by metallographical analysis of the tribological track after testing at room temperature and at $450^{\circ} \mathrm{C}$. The specimens with multilayer TiAlN coatings showed slightly better tribological properties, as regards the course of friction coefficient. Although the values of friction coefficient of multilayer coatings were comparable to the values determined for nanocomposite, the course of friction coefficient and analysis of tribo-tracks showed that the failure of the multilayer TiAlN coating was less pronounced compared to the nanocomposite coating.
\end{abstract}

Keywords: PVD, coating, temperature, ball-on-disc, friction coefficient, wear track.

\section{INTRODUCTION}

Working conditions place high demands on the quality of surfaces of stressed machine parts. Presently many technologies of surface treatment are available for increasing surface quality. Wear resistant layers have been used to reduce friction in moving machine assemblies. Many coating techniques have been developed, such as plasma spraying, physical vapour deposition (PVD), chemical vapour deposition (CVD), ion beam assisted deposition (IBAD) and their combinations [1]. They include production of thin and hard coatings on the surface of stressed materials by physical deposition methods. The PVD (Physical Vapour Deposition) process produces surface layers exhibiting high hardness, abrasion resistance and chemical and thermal stability. In many cases, they have also adequate corrosion resistance [2,3]. Today we know several tens of modifications of PVD procedures that undergo further development $[4,5]$. Their development is based particularly on the demand of the present market and extensive competition. The layers obtained by means of the arc method are characterized by a varied phase composition and structure, depending on the deposition conditions [6]. Recently, the frequent approach is the production of "custom made" coatings tailored to the specific use. It is the combination of individual layers with the specific composition arranged into multilayers, gradient layers or in the form of nanostructures that increase their market share and ensures their successful application in practice $[7,8]$. It is well known that the tribological properties are not inherent properties of materials, but are strongly systems and processes dependent. The tribological properties of all materials and coatings are thus strongly influenced not only by the operating test parameters (contact pressure, sliding speed

\footnotetext{
* Corresponding author. Tel.: +421-55-7922414; fax: +421-55-7922408. E-mail address: jakubeczyova@gmail.com (D. Jakubéczyová)
}

and counterpart materials) but also by the environmental factors including for example temperature and chemical composition of the environment $[9,10]$. The tribological properties of the layer - substrate system are related to the hardness, elastic module and adhesion of layers to the substrate [11]. Tribo test is a method for determining the wear of layers during sliding using a ball-on-disc apparatus. The friction coefficient (hereinafter called COF) depends on the thermal stability of coating which is affected by the structure [12-14]. The present paper deals with tribological properties of PVD layers at $20^{\circ} \mathrm{C}$ and $450{ }^{\circ} \mathrm{C}$. We characterized the wear behavior by COF and surface analysis with a track width after the tribo test.

\section{EXPERIMENTAL MATERIALS AND METHODS}

PVD layers were deposited by means of two physical vapor deposition processes (PVD) on the substrate of the conventional steel Böhler S600 Isorapid (C 0.9\%, Si $0.25 \%$, Mn $0.30 \%$, Cr $4.1 \%$, Mo $5.0 \%$, V $5.0 \%$, $\mathrm{W} 6.4 \%$ ) [15] with dimensions $\phi 30 \times 6 \mathrm{~mm}$. A multilayer TiAlN coating (TiAlN multi) was deposited by means of a system ARC PL 1000, equipped with four cathodes, and a nc- $\mathrm{Ti}_{1-\mathrm{x}} \mathrm{Al}_{\mathrm{x}} \mathrm{N}$ )/a-Si $\mathrm{S}_{4}$ (nACo) by means of a machine LARC $\pi-80$ (LARC®-LAteral Rotating Arc Cathodes) with two cathodes [16]. An improvement in this modern technology is based on rotating cathodes and their lateral position. During the process, evaporated metals and metal alloys enter the plasma state to combine with ionized process gas (nitrogen) and eventually condense on the substrate surface, as part of ceramic compounds. Amorphous and micro-nanocrystalline structures and layers develop under optimum thermodynamic and kinetic conditions. Spinoidal decomposition allows building of TiN nanocrystalline structures dispersed in a $\mathrm{Si}_{3} \mathrm{~N}_{4}$ amorphous matrix, with a typical crystallite size of about $10 \mathrm{~nm}$ [17]. After thermal processing to the hardness of 
$64 \mathrm{HRC}$ and $1280 \mathrm{HV} 0.5$ (the load $0.5 \mathrm{~N}$ ) the structure of the steel substrate consisted of tempered martensite and carbides. The microhardness of the substrate and the coatings was measured by Leco Micro Hardness Tester. Technological parameters of the PVD process are presented in Table 1, Table 2 and Fig. 1 a, b documented the quantitative EDX analysis of the investigated layers realised by JEOL JSM-7000F.

Table 1. Technological parameters of PVD process

\begin{tabular}{|c|c|c|c|c|}
\hline \multirow{2}{*}{ Coating } & \multicolumn{4}{|c|}{ Technological parameters } \\
\cline { 2 - 4 } & $\begin{array}{c}\text { Deposition } \\
\text { temperature, }{ }^{\circ} \mathrm{C}\end{array}$ & Current, A & Voltage, $\mathrm{V}$ & $\begin{array}{c}\text { Pressure, } \\
\mathrm{MPa}\end{array}$ \\
\hline TiAlNmulti & 430 & $\mathrm{AlTi} / 180$ & 40 & 1.0 \\
\cline { 3 - 4 } & $\mathrm{Ti} / 210$ & 160 & \multirow{2}{*}{75} & 1.4 \\
\cline { 3 - 4 } & 450 & $\mathrm{AlSi} / 82$ & $\mathrm{Ti} / 100$ & 75 \\
\hline
\end{tabular}

Table 2. Quantitative EDS analyse of PVD coatings

\begin{tabular}{|c|c|c|c|}
\hline Coating & Element & mass. \% & atom. \% \\
\hline \multirow{3}{*}{ TiAlNmulti } & $\mathrm{Ti}$ & 53.10 & 30.41 \\
\cline { 2 - 4 } & $\mathrm{Al}$ & 22.68 & 22.82 \\
\cline { 2 - 4 } & $\mathrm{N}$ & 24.22 & 46.77 \\
\hline \multirow{3}{*}{ nACo } & $\mathrm{Ti}$ & 57.24 & 34.23 \\
\cline { 2 - 4 } & $\mathrm{Al}$ & 16.72 & 17.35 \\
\cline { 2 - 4 } & $\mathrm{N}$ & 23.10 & 45.85 \\
\cline { 2 - 4 } & $\mathrm{Si}$ & 2.94 & 2.57 \\
\hline
\end{tabular}

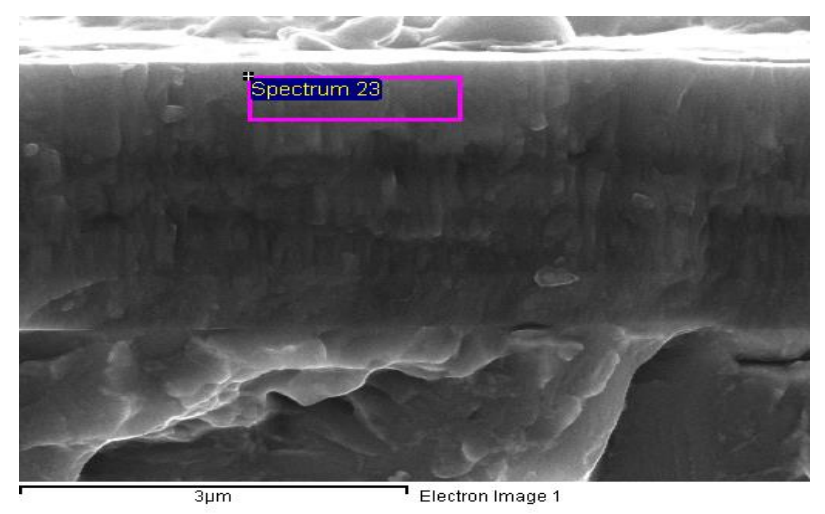

a

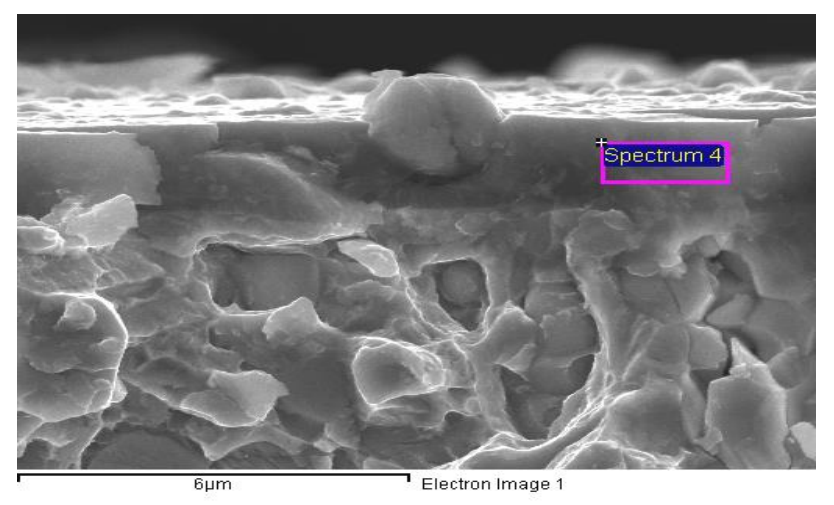

b

Fig. 1. SEM image of cross section microstructure of: $a$ - TiAlNmulti coating; $b$ - nACo coating, SEM

Thickness of the deposited layers was determined by Calotest and reached $2.6 \mu \mathrm{m}$ for TiAlNmulti layer and $1.8 \mu \mathrm{m}$ for nACo layer. The method is described in detail in $[18,19]$. The roughness of the layers was tested by profilometer Hommel Tester $\mathrm{T} 1000$ and achieved $\mathrm{Ra}=0.09 \mu \mathrm{m}$ for TiAlNmulti and $\mathrm{Ra}=0.07 \mu \mathrm{m}$ for $\mathrm{nACo}$.
Tribological properties of specimens coated with the PVD layer were tested by HT Tribometer CSM using a Ball-onDisc tribosystem (WC ball).

Table 3. Parameters of ball-on-disc test

\begin{tabular}{|c|c|}
\hline WC ball & $\emptyset 6 \mathrm{~mm}$ \\
\hline Speed of ball $v$ & $2,4,6 \mathrm{~cm} \cdot \mathrm{s}^{-1}$ depending on the radius \\
\hline Number of cycles $N$ & 10000 \\
\hline Load $L$ & $5 \mathrm{~N}$ \\
\hline Track radius $r$ & $2 ; 4 ; 6 \mathrm{~mm}$ \\
\hline Temperature & $20^{\circ} \mathrm{C}$ and $450^{\circ} \mathrm{C}$ \\
\hline
\end{tabular}

The wear tracks were examined by means of a light microscope Olympus GX 71 to provide a detailed analysis. The test conditions are presented in Table 3.

Mean values of microhardness HV 0.5 of individual layers, mean values of the COF for all measured radii (r) and the values of the track width are summarized in Table 4.

The wear track width was determined by image analysis and track depth by Sensofar PLu Neox. Hardness of thin layers is conditional on their structure which is affected by the character of the respective technological process [20]. In addition to the COF, other important evaluation criteria were the size and character of wear of the tribological track [21-23]. Appearance, size and chemical analysis of the track after the test were evaluated microscopically.

Table 4. The mean values of hardness HV0.5, friction coefficients $(\mathrm{COF})$, widths and depths of the wear track

\begin{tabular}{|c|c|c|c|c|c|}
\hline Coating & HV 0.5 & \multicolumn{3}{|c|}{$\begin{array}{c}\text { The COF a } \\
\text { measured radii 2, } 4 \\
\text { and } 6 \mathrm{~mm}\end{array}$} & $\begin{array}{c}\text { Width/depth } \\
\text { of the track, } \\
\mu \mathrm{m}\end{array}$ \\
\hline \multirow{8}{*}{ TiAlNmulti } & \multirow{8}{*}{2090} & \multirow{3}{*}{$\begin{array}{l}\text { Uे } \\
\text { ¿े }\end{array}$} & 2 & 0.684 & $353 / 0.822$ \\
\hline & & & 4 & 0.715 & $335 / 2.390$ \\
\hline & & & 6 & 0.765 & $350 / 1.928$ \\
\hline & & \multicolumn{2}{|c|}{ mean } & 0.721 & $346 / 1.713$ \\
\hline & & \multirow{3}{*}{$\begin{array}{l}0 \\
0 \\
0 \\
\\
\end{array}$} & 2 & 1.018 & $173 / 0.154$ \\
\hline & & & 4 & 1.033 & $263 / 0.218$ \\
\hline & & & 6 & 1.056 & $293 / 0.319$ \\
\hline & & \multicolumn{2}{|c|}{ mean } & 1.035 & $240 / 0.231$ \\
\hline \multirow{8}{*}{ nACo } & \multirow{8}{*}{2510} & \multirow{3}{*}{$\begin{array}{l}\text { Oे } \\
\text { }\end{array}$} & 2 & 0.740 & $370 / 1.626$ \\
\hline & & & 4 & 0.780 & 435 / 2.099 \\
\hline & & & 6 & 0.778 & $463 / 1.622$ \\
\hline & & \multicolumn{2}{|c|}{ mean } & 0.766 & $422 / 1.782$ \\
\hline & & \multirow{3}{*}{$\begin{array}{l}0 \\
0 \\
0 \\
7 \\
7\end{array}$} & 2 & 0.902 & $210 / 0.243$ \\
\hline & & & 4 & 1.083 & $263 / 0.340$ \\
\hline & & & 6 & 1.014 & $430 / 0.368$ \\
\hline & & \multicolumn{2}{|c|}{ mean } & 0.999 & $300 / 0.317$ \\
\hline
\end{tabular}

\section{RESULTS AND DISCUSSION}

Observation under a scanning electron microscope, Fig. $1 \mathrm{a}$, clearly showed the columnar structure of the TiAlN multi coating. The coat nACo in Fig. $1 \mathrm{~b}$ had compact, dense structure with characteristically high hardness and chemical and thermal stability [24]. The values of the microhardness, the COF for the measured radii of 2, 4 and $6 \mathrm{~mm}$ and the track width are presented in Table 4. The course of the COF for TiAlNmulti at $20{ }^{\circ} \mathrm{C}$ is illustrated in Fig. 2. The COF showed the most pronounced increase up to 1500 cycles, after which it stabilized in the interval from 0.65 to 0.75 . A moderate linear increase of COF to approx. 0.85 was observed up to 8000 cycles. After 
this time we could observe an evident decrease in COF at all radii of the wear track. The layer was re-ground down to the substrate and its surface was covered with products of friction (particularly titanium) and oxidation, i.e. aluminium oxide, which resulted in a decrease of COF for the final 8000 test cycles, as documented by wear tracks illustrated in Fig. 3.

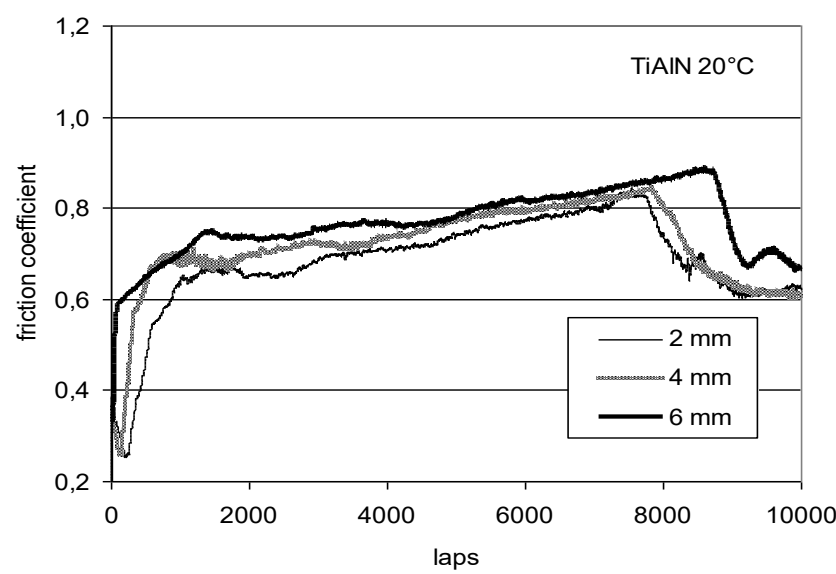

Fig. 2. Behaviour of the COF of TiAlNmulti coating at $20^{\circ} \mathrm{C}$

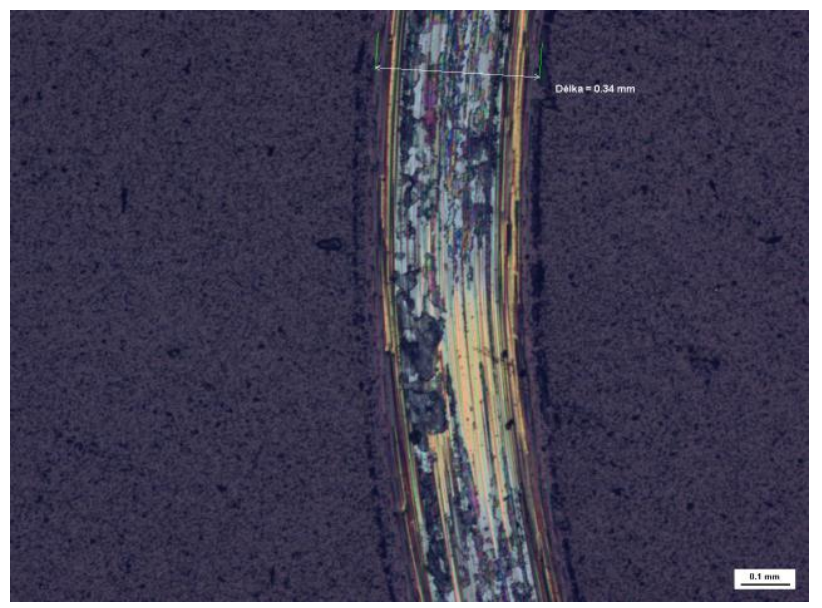

Fig. 3. The morphology of the wear track of TiAlNmulti with a radius $\mathrm{r}=4 \mathrm{~mm}$ and a width $0.34 \mathrm{~mm}(340 \mu \mathrm{m})$ at $20^{\circ} \mathrm{C}$, LM

Fig. 4 shows changes in COF and Fig. 5 the morphology of the material coated with TiAlN multi, that occurred at $450{ }^{\circ} \mathrm{C}$. The most pronounced increase in $\mathrm{COF}$ was recorded up to approx. 1000 cycles when it reached the level of 0.95 and showed a linear increase at all radii of the wear track. A local decrease observed for the $6 \mathrm{~mm}$ radius could be a consequence of external disturbing influences. The $\mathrm{COF}$ for individual radii gradually stabilized at the level of $1.05-1.15$. The character of the wear track for $\mathrm{r}=6 \mathrm{~mm}$ on the surface of the coating and LineScan EDS analysis illustrates the Fig. 6. LineScan analysis did not detect traces of $\mathrm{Fe}$ and base material was not exposed which indicated good adhesion of the coating to the substrate.

The edges of the track became rougher with large patches of adhering particles originating from the worn coating areas as demonstrated in Fig. 7.

A marked increase in $\mathrm{COF}$ for the nACo at $20^{\circ} \mathrm{C}$, Fig. 8, was observed already at the beginning of the tribological test. Up to 600 test cycles, the COF increased to the values of $0.7-0.8$ and an additional slower increase was observed at 3500 cycles to 0.9 for $\mathrm{r}=2 \mathrm{~mm}$ and to approx. 0.95 for track radii 4 and $6 \mathrm{~mm}$. After that we observed more uniform course of $\mathrm{COF}$ that stabilized at approximately 0.7 .

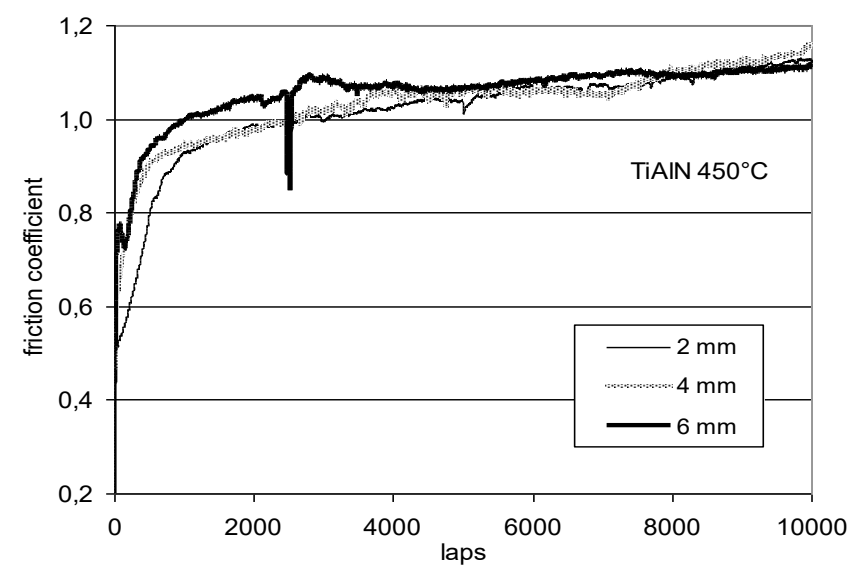

Fig. 4. Behaviour of the COF of TiAlNmulti coating at $450{ }^{\circ} \mathrm{C}$

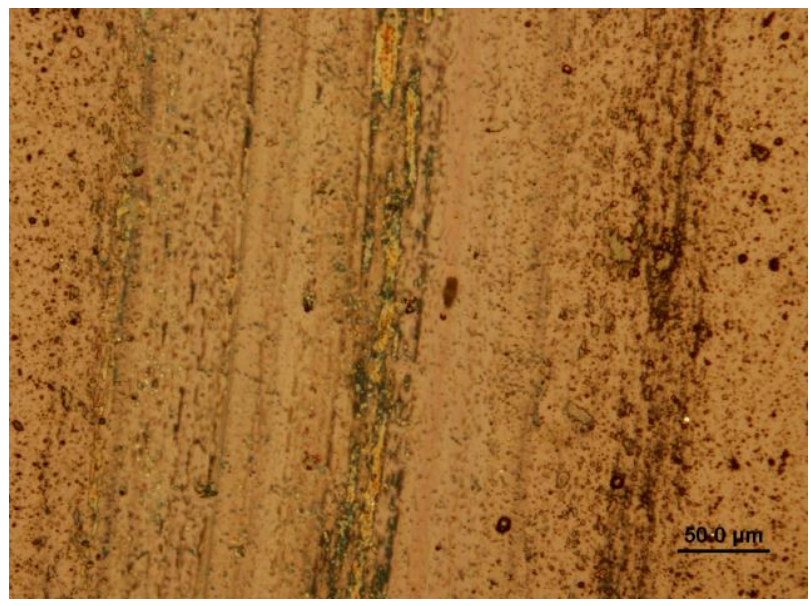

Fig. 5. The morphology of the wear track of TiAlNmulti with a radius $\mathrm{r}=6 \mathrm{~mm}$ at $450{ }^{\circ} \mathrm{C}, \mathrm{LM}$

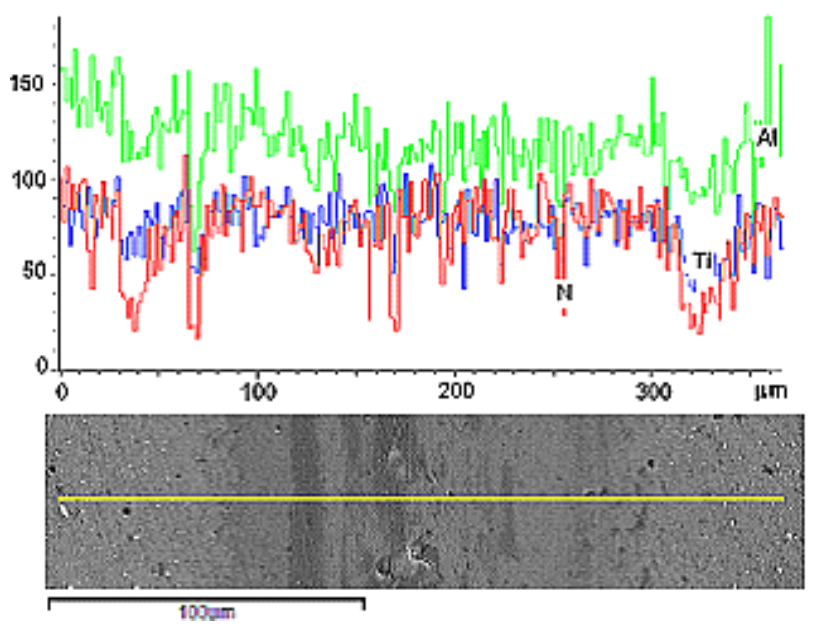

Fig. 6. The morphology of TiAlNmulti coating with the LineScan analyse of the wear track for $\mathrm{r}=6 \mathrm{~mm}$ at $450{ }^{\circ} \mathrm{C}$, SEM

The pronounced decrease in $\mathrm{COF}$ which could be ascribed to the formation of a sliding layer induced by $\mathrm{Ti}$, $\mathrm{Si}$ and $\mathrm{Fe}$ and also by products of oxidation, as illustrated the wear track for radius $\mathrm{r}=4 \mathrm{~mm}$ in Fig. 9 and the morphology of the wear track at $450{ }^{\circ} \mathrm{C}$ in Fig. 10 . 


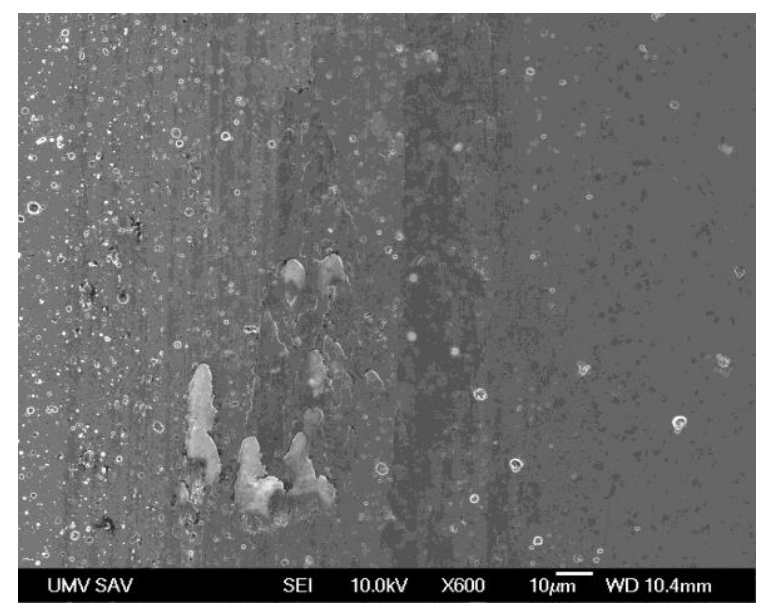

Fig. 7. The edges of the wear track with deposits of worn areas TiAlNmulti coating at $450{ }^{\circ} \mathrm{C}, \mathrm{SEM}$

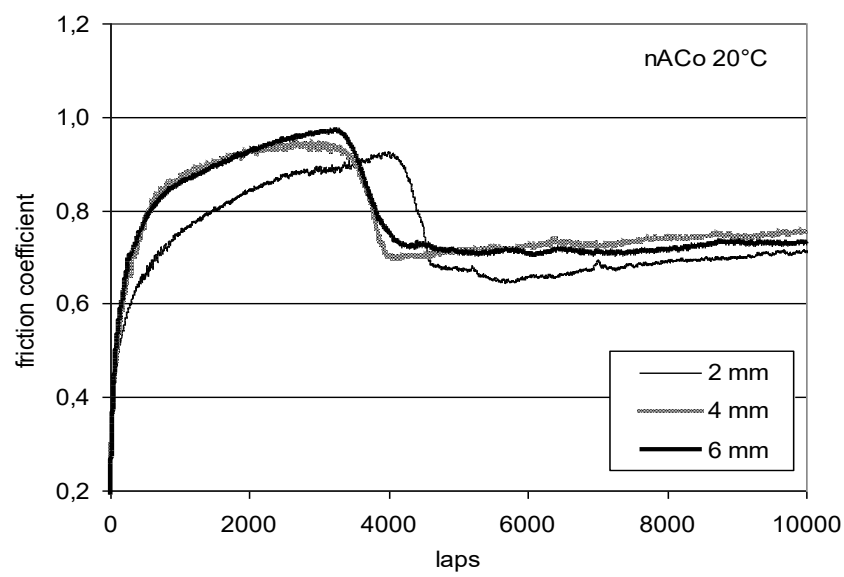

Fig. 8. Behaviour of the $\mathrm{COF}$ of the nACo coating at $20{ }^{\circ} \mathrm{C}$

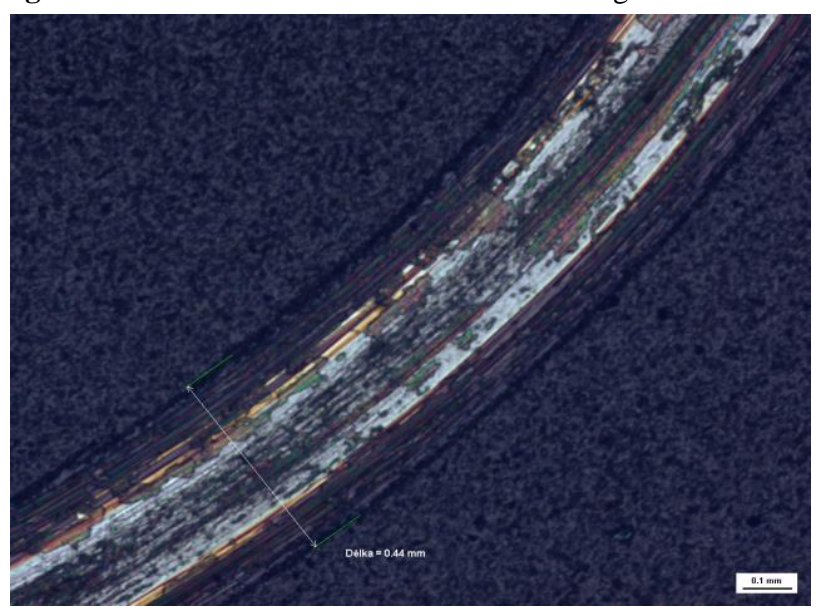

Fig. 9. The morphology of the wear track of nACo with a radius $\mathrm{r}=4 \mathrm{~mm}$ and a width $0.44 \mathrm{~mm}(440 \mu \mathrm{m})$ at $20^{\circ} \mathrm{C}, \mathrm{LM}$

Similar phenomena were reported in the study [25] that described changes related to wear of tribological systems during run-in which are mostly the consequence of surface topography, i.e. roughness and microstructure of the contact pairs coating - "pin body" and their interface. The study [26] presents tribological characteristics of the systems composed of commercial Ti-based coatings and nanocomposite nACo and counter body (ball) from hard metal. The nACo coating in comparison with the basic types of Ti-based coatings was more susceptible to wear. The COF for nACo was considerably higher, cracks appeared in the coating but the wear track was smoother.

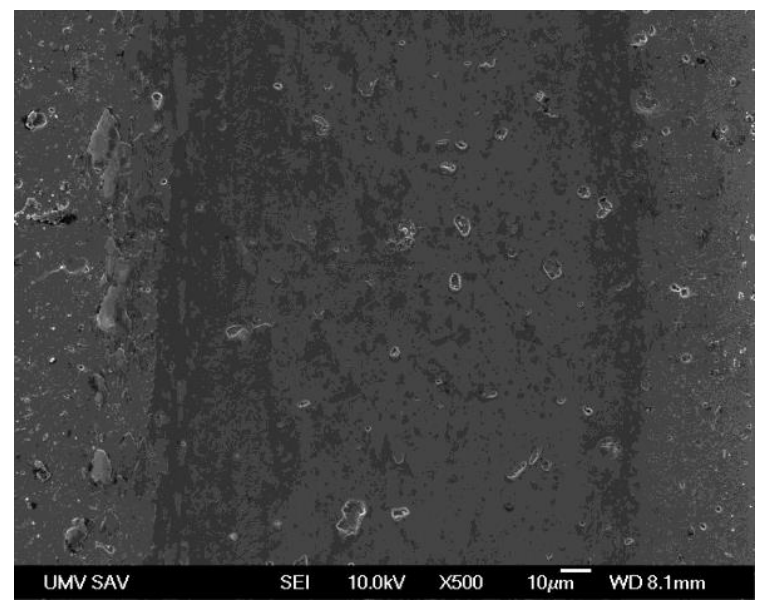

Fig. 10. The morphology of the wear track of nACo coating at $450{ }^{\circ} \mathrm{C}, \mathrm{SEM}$

The study [27] showed that lower hardness resulted in better resistance to wear. During the test the coating is stressed, undergoes slow wear and due to its relatively low hardness acts as a solid lubricant. In our study the hardness of tribological pairs coating - ball/pin differed (WC-ball; 17-24 GPa [28]). Nanometric harder fragments of coating are forced into micropores of the WC ball and act as an effective ,grinding tool“. Intensity of friction reduction of such ball during the test is indirectly proportional to its relative velocity on the coating and, gradually, the intensity of the ball reduction and its velocity on the surface become equal. Under such conditions, the grinding effect of pin on the surface of the coating is suppressed, coefficient of friction decreases and a sliding layer is produced.

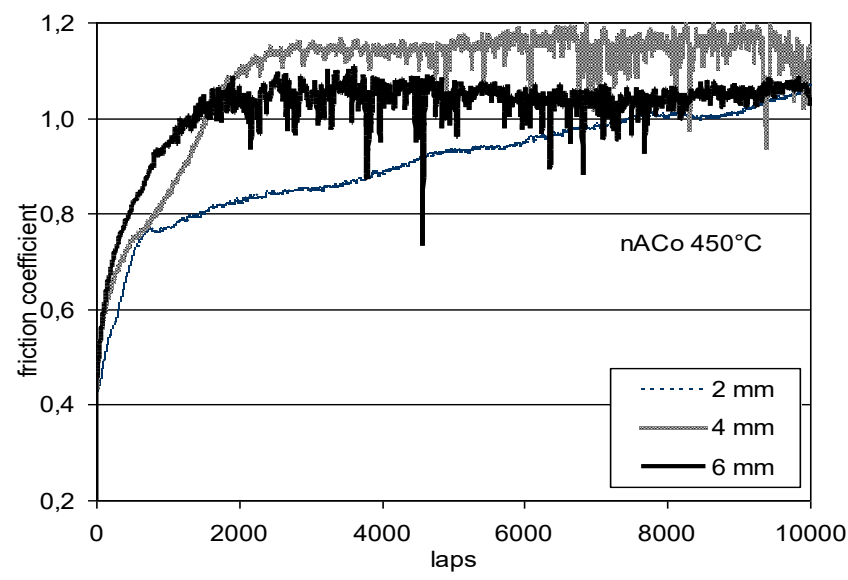

Fig. 11. Behaviour of the COF of nACo coating at $450{ }^{\circ} \mathrm{C}$

Fig. 11 shows the course of $\mathrm{COF}$ for the nACo tested at $450{ }^{\circ} \mathrm{C}$ and Fig. 12 illustrates the morphology of the wear track for $\mathrm{r}=4 \mathrm{~mm}$. The highest increase in COF was observed at radius of $\mathrm{r}=2 \mathrm{~mm}$ up to approx. 800 cycles and at radii $\mathrm{r}=4$ and $6 \mathrm{~mm}$ up to 1500 cycles.

After stabilization of its course, the COF ranged from 0.8 for radius $\mathrm{r}=2 \mathrm{~mm}$ up to the highest values between 1.05 and 1.1. After 2000 test cycles we observed a marked spread of values of the COF at track radii $\mathrm{r}=4$ and $6 \mathrm{~mm}$.

The LineScan analysis illustrated in Fig. 13 failed to detect the presence of $\mathrm{Fe}$ which indicates excellent adhesion properties of the respective system. Direct observation of contact between two bodies in movement is complicated. Generally, we must rely on the results of such 
observations and of relevant experiments and search for reasons that had caused the wear.

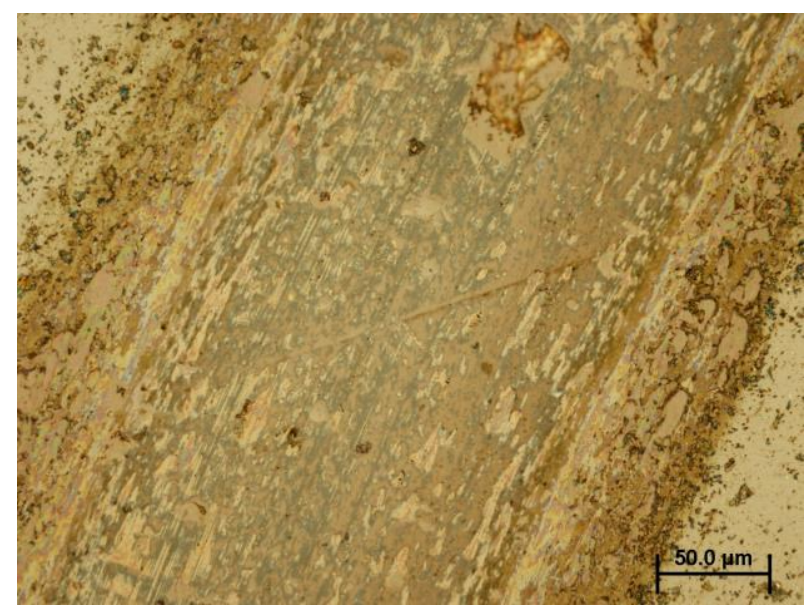

Fig. 12. The morphology of the wear track of nACo coating with a radius $\mathrm{r}=4 \mathrm{~mm}$ at $450{ }^{\circ} \mathrm{C}, \mathrm{LM}$
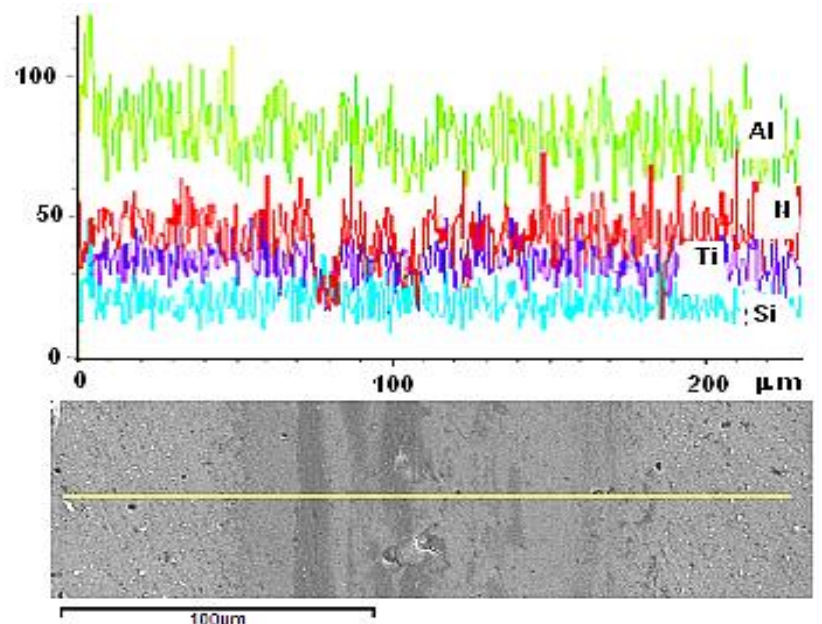

Fig. 13. The morphology of nACo coating with the LineScan analyse of the wear track for $\mathrm{r}=6 \mathrm{~mm}$ and at $450{ }^{\circ} \mathrm{C}$, REM

In many cases, the relevant processes occur at microscopic level which decreases accuracy of experiments. Wear is a very complex and dynamic process, dependent on many parameters, such as loading, material properties, lubrication, and other. Wear is a physical phenomenon which cannot be avoided. It is one of the tribological factors which affect significantly the service life of machine parts and equipment. [29].

\section{CONCLUSIONS}

The main idea of the contribution is the investigation of tribological properties of the PVD composite layers after Ball-on-Disc testing at room and at $450{ }^{\circ} \mathrm{C}$. From the realised analyses the following conclusions can be draw:

- The structure of the thin PVD layer depends on the essence of the coating process and on its technological parameters. The TiAlN multilayer produced by ARC technology had columnar structure. The nanocomposite nACo deposited by LARC method had compact dense structure.

- After coating, the microhardness HV0.5 of both coatings was higher in comparison with the substrate. The nanocomposite exhibited higher microhardness, namely
2510 HV0.5, than the TiAlNmulti that reached microhardness of $2090 \mathrm{HV} 0.5$.

- Tribological properties were determined by Ball-onDisc test and the COF and its changes during the test were investigated. The wear character of wear tracks after testing at $20^{\circ} \mathrm{C}$ and $450{ }^{\circ} \mathrm{C}$ were evaluated and documented by light, confocal and scanning electron microscopy. Behaviour of the nanocomposite nACo was better than that of TiAlN multi coating as shown by morphology assessment of the wear track. Testing at temperature of $450{ }^{\circ} \mathrm{C}$ showed no pronounced effect on failure of coatings which confirms excellent adhesion properties of the selected systems.

Comparison of TiAlNmulti and nanocomposite nACo coatings did not fulfil our expectations. We expected better tribological properties of the nACo coating. Our anticipations were not fulfilled or the employed method of testing of the respective coatings was only one of many others that allow one to obtain additional characteristics important for determination of quality of deposited coatings. The deposited types of coatings ensured increased hardness of the base material and the substratecoating interface was without relevant failures, which confirmed convenient adhesion properties of the system. Due to their specific properties, the coatings appear suitable for use in practical applications, e.g. coating TiAlN multi for drilling and universal use, also for weak machines and nACo nanocomposite coating for hard machining on stable machine, drilling, reaming and grooving [30].

\section{Acknowledgement}

The study was carried out within the framework of the national project VEGA 2/0061/14.

\section{REFERENCES}

1. Yang, J.F., Jiang, Y., Hardell, J., Prakash, B., Fang, Q.F. Influence of Service Temperature on Tribological Characteristics of Self-lubricant Coatings: A Review Frontiers Materials Science 7 (1) 2013: pp. 28-39. http://dx.doi.org/10.1007/s11706-013-0190-z

2. Macák, J., Pazderová, M. et al. Corrosion Properties of Vacuum Deposited Layers Chemical papers 101 2007: pp. 713 - 721 (in Czech).

3. Taktak, S., Ulker, S., Gunes, I. High Temperature Wear and Friction Properties of Duplex Surface Treated Bearing Steels Surface \& Coatings Technology 202 2008: pp. 3367-3377.

4. Lee, J.W., Duh, J.G. Nanomechanical Properties Evaluation of Chromium Nitride Films by Nanoindentation and Nanowear Techniques Surface \& Coatings Technology 188-189 2004: pp. 655-661.

5. Lee, J.W., Duh, J.G. Mechanical Property Evaluation of Cathodic Arc Plasma-deposited CrN Thin Films on Fe-Mn-Al-C Alloys Surface \& Coatings Technology 168 2003: pp. 223-230.

6. Jakubéczyová, D., Hagarová, M. Savková, J. Evaluation of Properties of Multilayer and Multicomponent PVD Coatings Deposited on Cutting Tools Produced by Powder Metallurgy Acta Metallurgica Slovaca 1 (18) 2012: pp. $13-19$. 
7. Chen, L., Wang, S.Q. Microstructure and Mechanical Properties of $\operatorname{Ti}(\mathrm{C}, \mathrm{N})$ and $\operatorname{TiN} / \mathrm{Ti}(\mathrm{C}, \mathrm{N})$ Multilayer PVD Coatings International Journal of Refractory Metals and Hard Materials 26 2008: pp. 456-460. http://dx.doi.org/10.1016/j.ijrmhm.2007.10.003

8. Warcholinski, B., Gilewicz, A. Tribological Properties of CrNx Coatings Journal of Achievements in Materials and Manufacturing Engineering 37 2009: pp. 498-504.

9. Gulbinski, W., Suszko, T. Thin Films of MoO3-Ag2O Binary Oxides - The High Temperature Lubricants Wear 26 2006: pp. $867-873$.

10. Colbert, R.S., Colbert, W.G. Thermal Dependence of The Wear of Molybdenum Disulphide Coatings Wear 269 2010: pp. 719-723.

11. Brezinová, J., Viňáš, J., Guzanová, A. The Quality Evaluation of Ceramic Coatings in Tribological Conditions and Cyclic Thermal load Chemical Papers 105 2011: pp. 574-576 (in Slovak).

12. Polcar, T., Cvrček, L., Široký, P., Novák, R. Tribological Characteristics of $\mathrm{CrCN}$ Coatings at Elevated Temperature Vacuum 80 2005: pp. 113-116.

13. Berger, M., Hogmark, S. Tribological Properties of Selected PVD Coatings when Slid against Ductile Materials Wear 252 2002: pp. 557-565.

14. Lukaszkowicz, K., Czyzniewski, A., Kwaśny, W., Pancielejko, M. Structure and Mechanical Properties of PVD Coatings Deposited onto the X40CrMoV5-1 Hot Work Tool Steel Substrate Vacuum 86 2012: pp. 1186-1194.

15. Jakubéczyová, D., Hagarová, M., Štěpánek, I. Evaluation of Thin PVD Coatings by Adhesive-Cohesive Test Annals of Faculty Engineering Hunedoara 2011: pp. 79-82.

16. http://platit.com/nanocomposites-coating

17. Settineri, L., Faga, M. G., Gautier, G., Perucca, $M$. Evaluation of Wear Resistance of AlSiTiN and AlSiCrN Nanocomposite Coatings for Cutting Tools CIRP AnnalsManufacturing Technology 57 2008: pp. 575-578.

18. http://www.stinstruments.com/uploads/editor/brochures/Calo test.pdf
19. http://www.csm-instruments.com/en/Calotest

20. Sgarabotto, F., Ghiotti, A. Tribological Behaviour of PVD Coatings for Sheet Metal Forming Tools: Laboratory and Industrial Evaluation Key Engineering Materials 504-506 2012: pp. 543-548.

21. Kovács-Coskun, T. Nano-Mechanical and Surface Morphological Properties of TiN Coating Produced by PVD on Tool Steel Materials Science Forum 659 2010: pp. $191-196$.

22. Derflinger, V.H., Schütze, A., Ante, M. Mechanical and Structural Properties of Various Alloyed TiAlN-based Hard Coatings Surface and Coating Technology 200 (16-17), 2006: pp. $4693-4700$.

23. Kniewald, D., Guzanová, A., Brezinová, J. Utilization of Fractal Analysis in Strength Prediction of AdhesivelyBonded Joints Adhesion Science and Technology 1 2008: pp. $1-13$

24. Holubář, P. Modern PVD Coatings for Cutting and Forming Applications MM The industrial spectrum 9 2004: pp. 106 (in Czech).

25. Blau-Peter, J. On the Nature of Running-in Tribology International 38 2005: pp. 1007-1012.

26. Lind, L., Adoberg, E., Aarik, L., Kulu, P., Veinthal, R. Tribological of PVD Coatings with Lubricating Films Estonian Journal of Engineering 18 (3) 2012: pp. $193-201$.

27. Kaczmarek, L., Stegliński, M., $\quad$ Sawicki, J., Świniarkski, J., Batory, D., Kyziol, K., Kołodziejczyk, L., Szymański, W., Zawadzki, P., Kottfer, D. Optimization of the Heat Treatment and Tribological Properties of 2024 and 7075 Aluminium Alloys Archiwes of Metallurgy and Materials 58 (2) 2013: pp. 535-540.

28. https://www.memsnet.org/material/tungstencarbidewcbulk

29. Žmindák, M. Numerical Simulation of the Wear Bodies in Contact (in Slovak) Tribotechnika 1 2014: pp. 26-29.

30. http://platit.com/coatings/main-application-fields-0 